\title{
Information Commons: A User- centered Information Service Mode
}

\author{
Xinyu Wang \\ library, \\ JiLin Agricultural University, \\ Changchun, China \\ Email: 729738677@qq.com
}

\author{
Qingsong Zhang \\ library, \\ JiLin Agricultural University, \\ Changchun, China \\ Email: 1007738301@qq.com
}

\begin{abstract}
Subject-oriented service now has entered a deep developing period, which urgently need to find a break through point and establish an implemental model that is feasible, sustainable and suitable for the new information environment; Information commons (IC), which is a new kind of service model offers a valuable opportunity in service innovation. This is the future trend of modern library service innovation and development. On the basis of the similarities of IC and subject-oriented service, this paper conceptualized the mode of subject information commons (SIC) and discussed the construction of SIC with respect to idea, basic tenets ,ultimate goals and content, the actualized strategies of establishing the information commons can finally be come into shape.
\end{abstract}

Keywords-information commons; subject-oriented service; actualized strategies;

\section{INTRODUCTION}

The construction of information commons (IC) is a new hot spot in the study of the current information service pattern in the library field. The American college and university libraries began to construct IC in the early 1990's. With the theoretical research deepening and entity building exploring, IC has already become one kind of main service pattern very well liked in European and American college and university libraries, representing a new trend in the development of university libraries abroad. The IC construction in our country is now in the early stage, with a few numbers of libraries having partial elements of IC. As a new integrated innovative service pattern which not only supports massed learning and private study but provides the perfect combination of technology and service for library users as well, college and university1-brary information commons satisfies the library users' changing demands for information, meanwhile, gains a good chance for the sustainable development.

User service in information age causes library organizations facing a new survival and development crisis. how to transform from traditional resources centered service to users centered subject service, becomes urgent topic which numerous library leaders and library organizations can't avoid, however, subject librarian system is the exploration and practice in subject service. Subject librarian is the information expert in some discipline subject, they are familiar with even are skilled in one or several subject knowledge, delegated by university library, contract with the academy or subject specially, and provide target-oriented subject information service ${ }^{\mathbf{1} 1 \mathbf{l}}$. Subject librarian system is one kind of high level personnel which established for university subject, serve for teaching an the scientific research, contract and navigate between the scientific research teaching units and library. Therefore, subject library is the service which needed for the adaptation of higher education reform development, manifest university library's diligent goal of management innovation and service innovation. and is vail for the information service in library integrating into the university teaching and scientific work, and is worth promoting safely and positively.

\section{SERVICE CONCEPT OF INFORMATION COMMONS}

For a long time, many libraries are engaged in enlarge its collection and ignores the real needs of people. IC requires the libraries to change its traditional concept of "focusing on collection" and to relocate itself. The libraries should establish the new concept of "focusing on users". Libraries should promote the interaction between information resources, service space and the personnel to eliminate the shortcomings of ambiguous responsibilities and lacking of cooperation. Library should restructure its business organizational mode and integrate the functions of its technology department, consulting department and reading room $^{[2]}$. Based on the integration of reading and borrowing, it should further integrate software resource and hardware resource, database and network information resource to provide services as consultation, information literacy training and media to users directly through IC. To solve the problems of the users is a "user-focused" service mode of one-stop, which brings the users a fresh experience. Only when the IC service concept is clearly defined, namely defining why to construct, how to construct and what to do with it, can the construction be of significance instead of being a new simple device upgrading.

\section{BASIC PRINCIPLES FOR IC}

\section{A Dynamic demands}

With the intensification of users' awareness, the demands of users tend to be diversified. First of all, the approach to information is diversified. Besides the check and borrowing by the user himself, he mostly relies on the 
librarian to pass to him. Second, as the inter-infiltration between disciplines and the rising of edge discipline, the user tends to demand diversified information and professional service $^{[3]}$. This requires IC to provide timely reaction towards user's dynamic demands with advanced informational service technology.

\section{$B \quad$ Integrated service}

IC is a place for research, teaching, learning and entertainment in the library. It should provide the users with integrated service of consultation, multi-media, research and skills. The user could get information by this integrated service at one stop in a shortest time at the lowest cost.

\section{Knowledge sharing}

IC is established to meet the user's personalized demands and to provide the user with platform for cooperation and information exchanging, which does not exist in traditional library service. In such a cooperative space, the user could get information directly through communication with other users, staffs and experts. He could also get network resource by the information devices of IC. It is an important place for information acquiring, knowledge sharing and knowledge innovation.

\section{GOALS OF IC}

No matter which mode IC adopts, its goals for its application in colleges are as follows: first is to provide a one-stop and personalized service to satisfy the user's information demands and learning. It allows the user to freely choose and acquire hardware devices, software resources, multi-media and network information resource to take fully advantage of the library resource. Second, the user can get help and consultation service from librarians, computer expert and media workers. The user can study and research under the guidance of the staff, which fully illustrates the philosophy of "user-focused". Third, it emphasizes centralized study or research to provide the user with a good environment for research and exchange. Fourth, it can train the user's ability to search, evaluate and use information thus leveling up his informational literacy. Finally, as a tool for the user's study and knowledge management, it can improve the user's creativity ${ }^{[4]}$.

\section{V.SERVICE CONTENT OF IC}

The information age has brought great changes to people's lives. University Library as the forefront of knowledge, bear the important mission of teaching, research, and development must pace with the times. In the context of the information age, people's behavior will also adapt to new situations and are subject to change. Concentrated expression of the traditional information service model difficult to meet user demand for personalized information, personalization has become the main demands of the information age. In view of this, the University Library Information Service Innovation Management is particularly important, which is to improve the quality of university library services to provide users with high-quality information resources is an important guarantee.

IC integrates the services that spread the campus and satisfies the use's need to study, research and teaching with an intact unified service of technology, resource, consultation and training. It promotes the integration of teaching, learning and studying as well as the managing service for network knowledge. First, IC combines with modern technology to expand the traditional library service and open up new service, for example, the library offers the service of lending of laptops, consultation pf electronic information, education and training of informational literacy, guidance for the usage of computer software and hardware, training and guidance for informational technology, support for informational technology(including code modifying, documents recovering, account management, wifi device, software installing, virus killing and so on) providing proper environment for academic study and creation. Second, IC makes the cooperation and coordination between the university and other departments possible. Within IC system, the other departments can provide services including multi-media classroom, writing training and guidance, language training and guidance, psychological consultation, and services from disabled students center. In addition, in some specialized library for research, IC may provide more professional service, like providing guidance and technological support for professional information resource, providing a service mechanism and cultural context that can promote cooperation, encourage innovation, offer guidance and adapt properly for cross-department and cross-profession service organizations and personnel for cooperative study and research ${ }^{[5]}$.

\section{STRATEGIES FOR CONSTRUCTION OF IC IN COLLEGE LIBRARY}

As the cradle for the IC, the theories and practices of American college libraries may of great help for us to construct IC and expansion of informational service.

\section{A Infusing the concept of IC}

As a place for independent study, team discussion and group research, IC succeeds in knowledge creation by inspiring users. In the construction and management of library, it becomes a trend to infuse the concept of IC to provide users with IC.

\section{B Planning for IC}

The planning for an IC is of great significance for its establishment. China starts later than some foreign countries, thus lacks of theoretical guidance. Therefore, in making plans, the library should based on its own software and hardware condition, make a plan that satisfies its users according to its own conditions and the users' habits with the help of foreign practices. 


\section{Construction of a reasonable IC service system}

Four construction factors have to be taken into consideration, namely, physical space, resources, service and the arrangement of personnel. For different users, different sizes of space should be set and different diversified service should be provided to realize the combination of virtual space and physical space.

\section{CONCLUSION}

With the deepening of social information, the trend of user's information needs and information behaviors change into diversification and personalization. As a service organizations, the traditional ideas and ways of service in libraries are difficult to meet readers' information needs gradually, so ,in order to cater to the needs of the community, libraries should better to reflect the functions of itself and must innovate service models and improve quality of service to meet the needs of readers constantly.

Information Commons(IC) is an one-stop service centers and collaborative learning environment. The successful Experience of IC in foreign countries has brought new opportunities to Chinese libraries. Many university libraries constructed their own IC service system. Learning from the successful experience of the IC at home and abroad and constructing Information Commons in libraries is an important ways and means to change the concept of the traditional services in library, and help to create a number of libraries with characteristics of the creativity.
With the new learning environment and technology condition, users' demand for the service content and service capacity of library levels up. The library in college should continuously explore new mode of service to adapt to the development of times. As an informational service mode for users, IC is an innovation in the service mode of college library. At the same time, it provides great opportunity for the development of the library. In actual work, the library can integrate according to its hardware devices, electronic resources, services and previous mechanism, the quality of its staff and knowledge structure to integrate flexibly to satisfy the users to the most and promote the development of IC.

REFERENCES
[1] Nancy Kranich. Libraries and the Information Commons
[EB/OL].(2003-12-03) Ala.org/ala/washoff/oitp/icprins. Pdf.

[2] USC Library.Information Commons: Learning Space Beyond the Classroom[EB/OL].(2004-09-16)

[2007-07-26].http://www.usc.edu/isd/libraries/lcations/leavey/news/c onference/presentations/.

[3] Ren Shuhuai, Sheng Xingjun. The Systematic Structure of the Information Commons and Its Actualized Strategies[J].Journal of Shanghai University,2008(9):149-160.

[4] Lu Ying. Construct Subject Information Commons and Expend Subject-oriented Service Areas[J]. Journal of Modern Information,2012(2):51-53.

[5] Xia Nanqiang, Chen Ming. Analysis of the Factors Influencing the Knowledge Sharing in University Library Information Commons in China[J]. Journal of Modern Information,2011(4):3-10. 